\title{
Research on the Talent Training Mode of Early Education Specialty Under the Background of Industry-Education Integration
}

\author{
Lingyu Bao* \\ Tongliao Vocational College, Tongliao 028000, Inner Mongolia Autonomous Region, China \\ *Corresponding author: Lingyu Bao, lingshi2007@126.com
}

Copyright: (C) 2022 Author(s). This is an open-access article distributed under the terms of the Creative Commons Attribution License (CC BY 4.0), permitting distribution and reproduction in any medium, provided the original work is cited.

\begin{abstract}
With the continuous progress of the society and the rapid development of the industry, the talent training mode of early education has become an important commodity of education reform. Under the background of the integration of industry and education, the training direction of early education professionals needs to be adjusted and planned. The practice of industry-education integration requires the deep combination of early education specialty with early education institutions and the technical standards of the equivalent industry, so as to build a high-quality platform for the growth of early education professionals. This paper focuses on the current situation of the integration of industry and education, and then makes an indepth analysis on several reform strategies, so as to lay a solid foundation for the training of early education talents.
\end{abstract}

Keywords: Industry-education integration; Early education specialty; Talent training mode; Reform strategies

Online publication: February 18, 2022

\section{Introduction}

With the help of school-enterprise cooperation and industry-education integration, it is possible to promote the practical teaching system, which is of great significance to the development of modern education and talent training. The integration of industry and education requires enterprises to participate in talent training. Therefore, colleges and universities should build a community of interests between enterprises and schools, realize mutual benefit and win-win outcomes, as well as help students to apply learned knowledge into their work ability. At present, the integration of industry and education has become an important channel for talent training in colleges and universities. This paper makes an in-depth analysis based on the industryeducation integration of early education specialty.

\section{Analysis on the connotation of early education}

In July 2010, the State Council integrated the content of early education for children aged 0-3 into the national education reform, in hope that relevant government departments will begin paying attention to the education of infants and young children. The following year, parents were given scientific professional guidance on feeding infants, so as to achieve the purpose of comprehensive early infant development. A series of policies issued by the State highlighted the State's attention to early infant development and care. By 2016, the State put forward the two-child policy, hoping to increase the number of infants and young children with this policy in hand. 
Through comprehensive analyses of infants and young children, scientists and scholars found that at the age of 0-3, which is the beginning of human growth and development, the body, mind, and psychology, begin to develop rapidly. It is precisely because of the particularity and importance of this stage that the State pays special attention to education in this age group. With the support and guidance of the State, many families have also realized the importance of early education. In this context, various types of early education institutions have been established, such as common early education institutions, early education centers, parent-child centers, parent-child clubs, and so on. Early education is of great significance to the healthy growth of infants and young children. It can significantly improve the comprehensive quality of infants and young children as well as lay a foundation for their healthy and vigorous growth.

\section{The current situation of promoting industry-education integration in early education specialty in higher vocational colleges}

\subsection{Imperfect policy mechanism of industry-education integration}

The reform of vocational education needs to assume the integration of industry and education, constantly improve the vocational education system, clarify the overall ideas and requirements of talent training, as well as affirm the importance of vocational education for social development. However, in order to realize the deep integration of industry and education, it is important to reform the current education system of the early education specialty. In the process of the integration of industry and education, the early education specialty has groped for a long time on the road of collectivization. With better comprehension about the integration of industry and education among early education majors and institutions, many practical activities involving cooperation between schools and early education institutions are carried out. Although the industry-education integration mode of early education specialty has been practiced for some time, it remains at the surface level. The more commonly used modes are the order mode or project cooperation. There are also great differences in the industry-education integration mode of early education specialty in different regions, reflecting that the policy has not formed a systematic and standardized system. There is no professional management system and evaluation as well as supervision organization. In addition, in recent years, the competitiveness of early education institutions has significantly increased, leading to reduced support for early education majors by early education enterprises.

\subsection{The integration of industry and education is a mere formality, and the cooperation between schools and early education institutions is not in-depth}

Enterprises aim at interests, and so do early education institutions. However, early education majors aim at talent training and school development. There are major differences in their starting points, which makes the development between schools and early education institutions easily formalized without any in-depth cooperation. The process of school-enterprise cooperation and the "interest barrier" between early education institutions and higher vocational colleges are the main reasons why the integration of industry and education faces difficulty. Early education institutions pay more attention to the training of their teachers, whereas most vocational colleges emphasize on theoretical teaching, which makes it difficult to integrate the training of early education institutions with that of vocational colleges. Therefore, the form of school-enterprise cooperative talent training should be stronger than the essence. In terms of policy, there are some differences between higher vocational colleges and early education institutions. If the benefits obtained by early education institutions are relatively small, the support for talent training of higher vocational education will gradually decrease. 


\section{Reform strategies of the talent training mode of early education specialty under the background of industry-education integration}

\subsection{Establish and improve the operation mechanism of school-enterprise cooperation}

After the implementation of the two-child policy, early education is booming, and the demand for early education talents is also showing a more vigorous situation. The factor influencing the talent training quality of early education specialty is whether the talent training program is set up scientifically, which will directly affect the quality of students. Under the guidance of the concept of industry-education integration and school-enterprise cooperation, schools should form an early education steering committee consisting of educators from government departments, infant education experts, and managers from early education institutions. On the principle of mutual benefit and complementary promotion, it is then possible to truly realize resource sharing, complementary advantages, and brand characteristic development. In consideration of the differences in the number of students, schools need to timely adjust their training plan and training time, integrate school resources, social resources, and early education institutions, as well as jointly formulate a gradient talent training system. On the basis of clarifying the tripartite functions, integrate the tripartite early education resources, build a cooperative work organization, and assume the integrated development of industry and education as well as the interactive development of schools and enterprises as the wage mechanism. Under the discussion of constructing a professional steering committee and work organization, it is also important to optimize the talent training system, curriculum system, graduation design, and other contents of early education specialty, as well as standardize the post-practice and training system, so as to stimulate the enthusiasm of early education institutions for cooperation through reward, thus realizing the seamless connection between schools and the talent training of early education industry while ensuring that both, schools and enterprises can obtain benefits.

\subsection{Scientific positioning of professional talent training objectives}

Setting the talent training goal of early education specialty is the starting point of educational development. It acts as a guide to key issues such as specialty construction and curriculum system setting. In recent years, with the implementation of the two-child policy, the early education specialty has expanded in terms of enrollment, so as to meet the demand of the market for early education talents. On the basis of a comprehensive survey of the market, schools need to follow the law of talent training of early education specialty and the characteristics of occupation to formulate talent training objectives. This goal should not only reflect the social adaptability of the specialty, but also take into account the diversified needs of social professional posts to ensure that the trained talents can adapt to different types of posts. When investigating the cooperation between early education institutions and the university, it was found that the main needs of these enterprises for employees are as follows: first, a certain language expression ability is needed to communicate with parents and children in a friendly manner; following that, the ability to deal with problems as exemplified by solving anxiety following employment and resolving conflict with other colleagues; finally, professional teaching skills are also required, including song playing and singing skills, dancing skills, accompaniment skills, painting skills, activity design skills, etc. These should be the skills that early education professionals should have. Based on the current development trend of early education, teachers should also encourage students majoring in early education to obtain various qualification certificates, such as nursery teacher training certificate, early education guidance certificate, as well as nutrition and healthcare certificate, so as to truly apply theoretical knowledge to practical operations, thus laying the foundation for subsequent employment. 


\subsection{Establish a solid and practical curriculum system}

In order to set up courses with professional qualification certificates in accordance with professional post qualification standards, it is necessary to ensure that the examination and courses correspond to one another; in addition, the practice links should be improved on the basis of the needs of the students and the society, so as to design diversified talent selection courses in meeting the current needs of early education enterprises in the search for compound and applied talents. Considering the skill standards of teachers in early education institutions issued by the State, practical courses should be offered, professional contents should be integrated into these courses, and rich teaching cases should be supplemented in extracurricular activities, research, and sex education, so as to improve the teaching effect. In the curriculum, schools need to ensure that the proportion of practical courses of early education specialty accounts for $60 \%$, in order to ensure sufficient time in improving the ten basic skills of students majoring in early education, such as speaking, playing, and singing. At the same time, skills competitions, professional knowledge competitions, and early education skills competitions should be arranged to help students and teachers master the latest development of the early education industry. If necessary, family education courses should be offered.

\subsection{Improve the practical teaching system inside and outside the school}

Professional development is inseparable from adequate teaching resources. Teaching resources can generally be classified into two types: the teachers' strength and the teaching base. In order to ensure that students majoring in early education develop at a faster rate with more stability, schools need to provide students with early education comprehensive simulation training rooms, dance rooms, manual training rooms, toys, picture books, infant healthcare rooms, etc., so that these students will be able to carry out simulation training in these simulated early childhood education environments to consolidate their foundation of early childhood education.

In terms of the construction of the actual base, schools can sign contracts with local early education institutions and cooperate with them to build training bases in the form of listing. Visitations to early education centers in batches can be carried out to understand how teachers in early education institutions prepare lessons, teach, and organize activities. This will improve students' professional application skills in all aspects.

\section{Conclusion}

Through comprehensive analysis and summary of the above contents, in order to improve the talent training system of early education specialty in higher vocational colleges, it is necessary to comply with the development situation of the integration of industry and education. When formulating the talent training model, teachers also need to fully consider the balance of practical teaching and theoretical teaching, so as to ensure the in-depth development of industry-education integration, thus comprehensively improving the practical skills of early education students.

\section{Disclosure statement}

The author declares that there is no conflict of interest.

\section{References}

[1] Huang D, 2020, Research and Practice on the Adaptability of Educational Practice of Early Education Specialty Under the Background of Industry Education Integration. Journal of Jiamusi Vocational College, 36(11): 82-84. 
[2] $\mathrm{Wu} \mathrm{Z,} \mathrm{2020,} \mathrm{Research} \mathrm{on} \mathrm{the} \mathrm{Curriculum} \mathrm{Teaching} \mathrm{of} \mathrm{Early} \mathrm{Education} \mathrm{Specialty} \mathrm{Under} \mathrm{the}$ Background of the Integration of Industry and Education - A Comment on the Principle and Practice of Early Education. Educational Theory and Practice, 40(24): 2.

[3] Zheng G, 2020, Exploration of Practice and Training System of Early Education Specialty Under the Background of Industry Education Integration. Journal of Hubei Open Vocational College, 33(13): 2426.

Publisher's note

Bio-Byword Scientific Publishing remains neutral with regard to jurisdictional claims in published maps and institutional affiliations. 